\title{
Enterprise Governance of Micro Entrepreneurs in Malaysia: Comparison between the Amanah Ikhtiar Malaysia and Asnaf's Economic Development Program
}

\author{
Farah Aida Ahmad Nadzri (Corresponding author) \\ Accounting Research Institute, Universiti Teknologi MARA, Shah Alam, Selangor \\ Tel: +6019-3299184 E-mail: aidanadzri@uitm.edu.my \\ Normah Omar \\ Accounting Research Institute, Universiti Teknologi MARA, Shah Alam, Selangor \\ Tel: +603-5544 4924 E-mail: normah645@salam.uitm.edu.my \\ Rashidah Abdul Rahman \\ Faculty of Economics and Administration, King Abdul Aziz University, Jeddah \\ Tel: +966543126672 Email: rabdulwahid@kau.edu.sa
}

\begin{abstract}
Enterprise governance is vital for all types of organizations, including micro entrepreneurs, as it is closely related to performance. Considering that repayable and non-repayable types of microfinance programs exist in Malaysia, this study examines whether different types of financing affect the financial and non-financial performances of micro entrepreneurs. Based on the questionnaires distributed to 485 micro entrepreneurs from Amanah Ikhtiar Malaysia (AIM) and Pusat Pembangunan Usahawan Asnaf Zakat Selangor, followed by interview sessions with 17 of them, this study found that although asnafs financially perform lower than the AIM sahabats, asnafs are generally more satisfied with their overall conditions. The findings suggested that both types of financing have their strengths and weaknesses. Therefore, to improve the current overall practice of microfinance programs in Malaysia, non-repayable programs were recommended to focus on hardcore poor entrepreneurs, whereas repayable programs were advised to focus on the poor category.
\end{abstract}

Keywords: enterprise governance; micro entrepreneurs; types of financing; Amanah Ikhtiar Malaysia; Pusat Pembangunan Usahawan Asnaf Selangor

\section{Introduction}

Enterprise governance (EG) or corporate governance $(\mathrm{CG})$ is a concept related to the rules and structures for effective business management and high performance. Having an effective EG sets an expectation for an organization to be well managed, sustainable, and capable of outperforming its competitors (Ball, 2016). Despite the small size of micro entrepreneurs, the EG concept is still relevant to them. In the context of micro entrepreneurs, EG refers to the set of responsibilities or roles of the owners in ensuring that their business objectives are achieved, risks are managed, and resources are optimally utilized. Although Orford et al. (2003) suggested that the primary source of funds for small and micro entrepreneurs were either their own savings and income or financing from their personal networks (e.g., family members and friends), increasing trends are observed for these micro entrepreneurs to receive financial assistance from microfinance institutions (MFIs) (Kazemian, Abdul Rahman, Mohd Sanusi, \& Adeyemi, 2016).

Microfinance is related to providing smallscale financial services (mainly savings and credits) to small or micro entrepreneurs (Robinson, 2001). The concept was introduced by Professor Muhammad Yunus in the 1970s 
in Bangladesh, with the aspiration to improve the poor people's lives by providing them access to financial services. The program has then been developed into a full-fledged MFI, namely, the Grameen Bank, and replicated by many countries, including Malaysia (Gibbons \& Kassim, 1990; Kazemian, Abdul Rahman, \& Ibrahim, 2014; Omar, 2010; Todaro and Smith, 2006). In Malaysia, repayable micro financing is provided by various MFIs, such as Amanah Ikhtiar Malaysia (AIM), TEKUN Nasional, and Yayasan Usaha Maju (YUM) in Sabah. Apart from MFIs, other existing organizations, such as Zakat institutions (ZIs) and various non-government organizations (NGO), provide non-repayable micro financing to micro entrepreneurs in the country.

Previous studies in microfinance have constantly highlighted the success of repayable microfinance programs worldwide to alleviate poverty in the respective countries. Aside from Grameen Bank, ACCION's BancoSol in Bolivia, Bank Rakyat Indonesia's Unit Desa program in Indonesia, and AIM in Malaysia are examples of MFIs deemed successful in improving the income of their clients (Mamun, 2016; Revindo \& Gan, 2017; Sina, Sabur \& Kamaruzzaman, 2017). Nevertheless, the performance of nonrepayable programs has been disheartening. As an example, Hussin and Ahmad (2010) reported that, overall, only $6.9 \%$ out of 537 respondents who received capital aid from Zakat institutions in Selangor and Kuala Lumpur managed to pass the Kifayah level of poverty. Another study by Che Yaacob et al. (2013) on the performance of asnaf in Johor also found that only $13 \%$ out of 173 capital aid recipients managed to earn over RM1,000 per month, while another 33.5\% had income between RM300 and RM900 only.

Moreover, a study by Hamdan, Othman, and Wan Hussin (2012) on the effectiveness of four microfinance programs, namely, Lembaga Zakat Selangor (LZS), Yayasan Basmi Kemiskinan (YBK), AIM, and TEKUN, found that the mean income of AIM participants is highest at RM2,038, followed by TEKUN at RM1,994.
By contrast, LZS and YBK participants scored mean incomes of RM1,515 and RM425, respectively. Compared with the AIM and TEKUN participants, the LZS and YBK participants from are not required to make any repayment to the agencies, suggesting that the performance of participants in repayment schemes is significantly higher than those in non-repayable programs.

Despite various studies on the performance of micro entrepreneurs, little is known regarding the reasons for the lower performance of participants in non-repayable programs compared with those in repayable programs. Accordingly, this study attempts to reduce the gap using Free-rider theory. This study adopts a mixed method approach to examine whether the two types of financing affect the performance of micro entrepreneurs. For the purpose of this study, members of the largest MFIs in Malaysia, AIM, and recipients of capital financing under Pusat Pembangunan Usahawan Asnaf Zakat Selangor (PPUAZ) or Asnaf Entrepreneurs Development Centre Selangor were selected for investigation. AIM members, also known as sahabats, represented the recipients of repayable micro financing, while asnafs from PPUAZ represented the recipients of non-repayable micro financing.

Following this first section, Section Two reviews the related literature on micro financing in Malaysia and on Free-rider theory. Section Three, the Methodology section, clarifies the methods used to carry out this research. Section Four presents the results and discussion. Finally, Section Five concludes and summarizes the findings of this study based on the initial research objective. 


\section{Literature Reviews}

\section{Micro Financing in Malaysia}

Microfinance programs in Malaysia can generally be divided into two categories: repayable and non-repayable micro funds. AIM, TEKUN Nasional, and YUM are among the major MFIs in Malaysia that offer repayable micro funds to eligible micro entrepreneurs. By contrast, the non-repayable micro funds are provided by various ZIs (e.g., Selangor, Penang, Negeri Sembilan, and Kuala Lumpur) and NGOs, such as YBK.

AIM is considered the oldest and biggest MFI in Malaysia. Started from a pilot project in 1986 in Northwest Area Selangor, AIM is currently serving over 350,000 clients all over Malaysia with cumulative financing of over RM12 billion (AIM, 2016). Empirical studies conducted on AIM confirm that the program has a positive socio-economic impact. For example, the eight Impact Study conducted by UKM in 2009 found a $259 \%$ increase in the incomes of sahabats after they joined AIM compared with a $22 \%$ increment for the control group (those qualified to join AIM but refused to participate). The study also revealed that the poverty incidence of sahabats declined by $45 \%$ compared with the $6 \%$ for the control group. Moreover, the study found positive impacts of AIM on expenditures, savings, ownerships of assets, accessibilities to public facilities, and women empowerment. The study covered all 13 states in Malaysia, with a total of 1,295 respondents (UKM Pakarunding, 2010). The latest impact study was conducted by the Accounting Research Institute, Universiti Teknologi MARA. Using financial diaries as instruments, the study found that $25 \%$ out of 393 sahabats managed to earn over RM5,000 per month, suggesting that a number of sahabats are no longer classified as poor (Accounting Research Institute, 2015).

\section{Zakat as Non-repayable Micro Funds}

The word "al-zakah" is mentioned 30 times in the Holy Quran (Al-Qaradawi, 1999). Literally, Zakat means to grow and to increase; whereas in Shari'ah, Zakat is a concept referring to the redistribution of wealth prescribed by God to the deserving category of people. Apart from poverty eradication, Zakat aims to eliminate greediness among Muslims and encourage socially oriented behavior (Ab Rahman, Alias \& Syed Omar, 2012). In Malaysia, the Zakat fund is managed by ZIs in every state (Rahman, Rahman, Thaidi, Abdullah, Anwar, Bakar \& Ahmad, 2013). According to Abdul Rahman and Ahmad (2010), the Zakat distribution method is still focused on the periodical form of direct payment, where an asnaf is given Zakat money either monthly or annually. However, it is argued that the direct payments of Zakat do not solve the poverty issues in the Muslim community, as these payments may reduce the asnafs 'willingness to work and they may end up being dependent on the Zakat funds for living (Abdul Rahman, Al Samdy, \& Kazemian, 2015; Abd Wahab, 2012; Ibrahim, 2008; Md. Hassan, Mohd Nor \& Mohd Rom, 2012). Although direct payment of Zakat is still acceptable, especially for the non-productive asnafs (e.g., the disabled and elderly), Zakat is recommended to be distributed in the form of capital finance to the poor and the needy to encourage business activities among the asnafs. In the long run, the productive asnafs are expected to gain future independence, with the ability to support themselves and their families and consequently escape poverty (Ibrahim, 2008). In Islam, working and seeking a livelihood are obligations of a Muslim as Prophet Muhammad (pbuh) reportedly said: 


\begin{abstract}
"It is far better for you to take your rope, go to the mountain, (cut some firewood) carry it on your back, and sell it and thereby save your face than begging from people whether they give you or refuse."
\end{abstract}

\section{(Hadith - Sahih Bukhari)}

Realizing the importance of distributing Zakat in the form of capital finance, several ZIs (e.g., Kuala Lumpur, Negri Sembilan, Penang, and Selangor) have been active in distributing Zakat funds to finance the businesses of asnafs. Given that other ZIs are focusing on providing capital assistance in monetary form, Selangor decided to vary their assistance in the form of training and exposure to the recipients to create "asnaf entrepreneurs" (Mohd Balwi \& Abdul Halim, 2008). Thus, PPUAZ was established in July 2011 as a subsidiary of Majlis Agama Islam Selangor (PPUAZ, 2012) mainly to manage and monitor the asnaf entrepreneurs based on the clustered projects. The function of PPUAZ is segregated from that of the Selangor Zakat Board (SZB) because the former focuses on providing capital finance to asnaf entrepreneurs in the clustered projects, whereas the latter distributes other types of Zakat assistance, such as individual entrepreneurs, monthly financial allowance, medical assistance, and housing assistance (Abdul Wahab, 2012; PPUAZ, 2012). Based on the PPUAZ official figure in April 2013, a total of 116 asnafs had participated actively in the PPUAZ economic development program. Under PPUAZ, asnaf entrepreneurs were grouped into seven clustered projects based on their economic activities, such as "My Burger," "Mobile Entrepreneur," and "Craft." Some of these projects are the continuation of the programs carried earlier by the SZB (PPUAZ, 2012).

However, when compared with the performance of sahabats from AIM, the performance of asnaf entrepreneurs were discouraging. Hussin and Ahmad (2010) studied the impact of the amount of capital provided to the asnafs on the success of their businesses. A survey on 534 asnafs who have received capital assistance in Selangor and Kuala Lumpur found that the percentage of successful asnafs was highest when they were given moderate amounts of capital between RM5,000 and RM20,000 than when they were given small and large amounts of capital. In the study, RM1,000 to RM5,000 were considered small, while RM20,000 was classified as large. Overall, the study found that only 37 out of 534 participants successfully earned income beyond the level of kifayah. Based on the findings, the capital financing program under the MAIWP and LZS seemed ineffective in improving the income level of the participants. Similarly, by referring to the MAIS Audit Sample Report from 2004 to 2006, Hamdan, Ahmad, and Othman (2012) found that only $9 \%$ of the participants in the economic development program (EDP) are considered successful in maintaining and growing their businesses, while the percentage of failure is around $32 \%$. By contrast, approximately $48 \%$ of the asnafs are considered unchanged because no changes were observed in their income after they joined the EDP.

\section{Free-rider Theory}

Free-rider theory is often used to explain the situation where an individual is receiving benefits without any or little cost borne by him or her. Albanese and Van Fleet (1985) explained Olson's Free-rider theory by arguing that it was originally concerned with the provision of public goods to a large group of individuals. Theoretically, providing free products or services to individuals may result in inefficiency and under-provision of those goods or services (Cullitty, 1995; Russell, 2003; Hadi \& Kamaluddin, 2015). In economic literature, studies suggested that providing "free money" or grants to recipients may result in an inefficiency of fund utilization.

The comparative merits of repayable loans or non-repayable grants have long been disputed, 
especially within the context of foreign-aid programs. However, similar issues have also been highlighted in other types of recipients, such as university students (student loans versus scholarships); small firms (direct subsidies, such as agricultural subsidies versus government grants versus private financing); and individuals, especially the poor and needy (government grants versus credit) (Alam, Hassan, \& Said, 2015; Bergstrom, 2000; Cordella \& Ulku, 2004; Klein \& Harford, 2005; Kurwijila \& Due, 1991; Morrissey, Islei M'Amanja, 2006; Woodhall, 2002).

Grants are normally associated with "free money" because the recipients have no obligations to repay (Morrissey, Islei \& M'Amanja, 2006). The concept is similar with the asnafs covered in this study, because they are not required to make any repayment to PPUAZ. However, as Muslims, the asnafs are expected to pay Zakat in the future based on their income once they have the ability. The future Zakat payment is part of their responsibility as a Muslim and is not a repayment for the Zakat assistance received earlier. Conversely, loans are related to an obligation to repay, which depends on the borrowing terms and conditions (Morrissey, Islei \& M'Amanja, 2006). To illustrate, sahabats in this study are required to repay their loans to AIM weekly during their weekly meetings. Although no legal action will be taken by AIM for loan default, in the aqad, sahabats pledge that they will be responsible for their loans; moreover, Allah/God is a witness to all their words and actions (Hasan, 2013; Mohd-Sanusi, et al., 2015).

From the literature, resolving the "nonrepayable grants versus repayable loans" issue seems a critical concern, and several aspects require consideration to determine the best method to finance the poor. Although the issues have been discussed in detail, especially with regard to the financing of poor countries, a limited number of empirical studies compare the impacts of providing non-repayable grants or repayable loans to the poor individual.
Theoretically, free money is suggested to lead to inefficiency. Thus, this study attempts to look at the impact of different types of financing, namely, Zakat capital financing (non-repayable) and AIM micro financing (repayable), on the financial and nonfinancial performance of micro entrepreneurs.

\section{Methodology}

EG is a concept related to both corporate and business governance (CIMA, 2007). While CG is closely related to conformance, business governance, on the other hand, is concerned with business performance. By focusing on the business governance aspect, this study intends to examine the effect of different types of financial capital (repayable and non-repayable financing) on the performance of micro entrepreneurs. To meet this main objective, this study adopted a mixed method approach that combines quantitative (surveys) and qualitative (interviews) approaches. The surveys were conducted first to provide the overall and background information of the micro enterprises and their financial management practices. Then, the findings from the questionnaire were verified in interview sessions with selected micro entrepreneurs.

The survey data were gathered from 485 samples comprising 392 samples from AIM and 93 samples from PPUAZ. The survey was conducted between April and June 2015 for AIM, while the questionnaire was distributed to the micro entrepreneurs of PPUAZ from July to December 2015. From the 392 samples, $76(15.67 \%)$ were from Kuala Selangor, 77 (15.87\%) from Kuala Langat, 62 (12.78\%) from Hulu Langat, 67 (13.82\%) from Sepang, $44(9.07 \%)$ from Barat Laut Selangor, and 66 (13.61\%) from Hulu Selangor.

According to the official AIM figure, in 2013, there were a total of 21,214 active sahabats in six AIM branches in Selangor. However, during the data collection stage of this study, AIM did not have official figures on the sahabats 
involved in micro businesses. Thus, following Cochran's calculation, a total of 384 samples from AIM were required for this study. The purposive sampling method was adopted in this study, and samples were chosen based on the participants' willingness to participate. However, to ensure that the questions were answered by the targeted respondents, prior to answering the survey questions, the participants were asked whether they were actively involved in running a business. Alternately, given that the population of the PPUAZ micro entrepreneurs was known (116 asnafs), Yamane's formula suggested 90 samples to be collected from PPUAZ. Similar to AIM, samples from PPUAZ were collected based on their willingness to participate in the study. A total of 93 questionnaires were collected from the PPUAZ micro entrepreneurs for the purpose of this study. The interviews were then conducted in November and December 2015 via telephone after all the data from the surveys had been thoroughly analyzed. Based on feedback from participants on the questionnaire, 17 (12 sahabats, 5 from PPUAZ) were interviewed.

\section{Results and Discussion}

\section{Financial Performance}

Consistent with previous studies on the performance of micro and small businesses, financial performance in this study was measured using the amount of sales and profit (Chrisman, McMullen \& Hall, 2004; Chrisman
\& McMullen, 2005; Du Rietz \& Henrekson, 2000; Fairlie \& Robb, 2009; Zou, Chen \& Ghauri, 2010). Given that micro enterprises generally have no proper accounting record, participants in this study were required to report their average monthly sales and profit in the survey form. However, by focusing on the amount of sales and profits per se, we tend to miss the overall picture of these micro entrepreneurs. Referring to the amount of capital invested in the micro enterprises, the amount seems to be widely spread between RM500 and RM130,000. Moreover, as illustrated in Figure 1 , the average capital utilized by respondents from AIM is RM15,607, and the amount is double than the average capital employed by respondents from PPUAZ, which is only RM8,030. This finding verifies that the amount of capital invested by the sahabats is significantly higher compared with that by the recipients from PPUAZ. As highlighted by Robb and Watson (2012), improving the usefulness of the financial performance measurements requires these details to be related to other information, such as the amount of money invested in the business. Thus, the return on equity (ROE) of each participant in this study was calculated based on their self-reported profit and total capital during the analysis process. With ROE as one of the performance measurements, the size of the capital investment was properly controlled in this study.

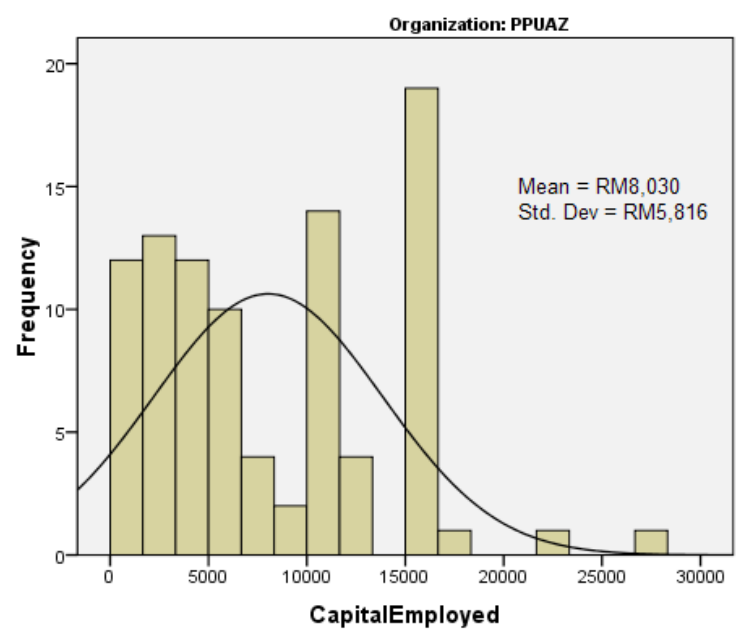

Figure 1: Histogram of Total Capital Utilized for each Organization 
To compare the means of financial performance between the AIM and PPUAZ participants, the mean tests were conducted using SPSS 20.0. Table 1 summarizes the financial performance of the micro entrepreneurs in AIM and the asnaf's EDP on the basis of the amount of sales, profit, and ROE. Table 2 shows the results of the independent sample t-test. Prior to conducting the independent sample t-test, the test of equality of variances, specifically Levene's Test, was conducted. The results from the sample, which were divided into AIM and PPUAZ participants, suggested that the mean for these two groups are significantly different.

Levene's Test in Table 2 shows that the variance of sales amount for the two groups (AIM and PPUAZ) is significantly different $(\mathrm{sig}=0.000<$
$0.05)$; hence, the results in the second row were used. The t-test provides evidence that the sales amount between AIM and PPUAZ respondents are significantly different, $\mathrm{t}=0.000<0.05$. Therefore, the null hypothesis was rejected. On average, the monthly sales of the sahabats are higher at RM5,421 (standard deviation = RM7,776) compared with those of the PPUAZ recipients at RM2,391 (standard deviation $=\mathrm{RM} 2,434)$. This difference is statistically significant at the 0.05 significant level, $\mathrm{t}$ (452) $=6.490, \mathrm{p}=0.000<0.05$. Moreover, adequate evidence also suggests that a significant difference exists in the profit performance of AIM sahabats $(\mathrm{M}=\mathrm{RM} 2,520, \mathrm{SD}=\mathrm{RM} 3,189)$ and PPUAZ asnafs $(\mathrm{M}=\mathrm{RM} 1,070, \mathrm{SD}=$ $\mathrm{RM} 1,019) ; \mathrm{t}(448)=7.524, \mathrm{p}=0.000$.

Table 1: Financial Performance of Micro Entrepreneurs

\begin{tabular}{|c|c|c|c|c|c|}
\hline & $\mathbf{N}$ & Minimum & Maximum & Mean & Std. Deviation \\
\hline \multicolumn{6}{|l|}{ Sales (RM) } \\
\hline AIM & 392 & 150 & 50000 & 5421.43 & 7776.372 \\
\hline PPUAZ & 93 & 200 & 16000 & 2391.4 & 2434.028 \\
\hline & 485 & 150 & 50000 & 4840.41 & 7169.682 \\
\hline \multicolumn{6}{|l|}{ Profit (RM) } \\
\hline AIM & 392 & 100 & 26000 & 2520.54 & 3189.285 \\
\hline PPUAZ & 93 & 100 & 8000 & 1070.97 & 1019.413 \\
\hline & 485 & 100 & 26000 & 2242.58 & 2956.511 \\
\hline \multicolumn{6}{|l|}{ Return on Equity (RM) } \\
\hline AIM & 392 & 0.01 & 1.6 & 0.2238 & 0.21188 \\
\hline PPUAZ & 93 & 0.01 & 2 & 0.2816 & 0.33492 \\
\hline PPUAZ-Adjusted & 93 & -0.1 & 1.4 & 0.1752 & 0.24839 \\
\hline & 485 & 0.01 & 2 & 0.2349 & 0.24105 \\
\hline
\end{tabular}


GJAT | JANUARY 2018 | SPECIAL ISSUE | 32

ISSN : 2232-0474 | E-ISSN : 2232-0482

www.gjat.my

Table 2: Independent Sample t-Test (based on Sales, Profit, ROE, and Adjusted ROE)

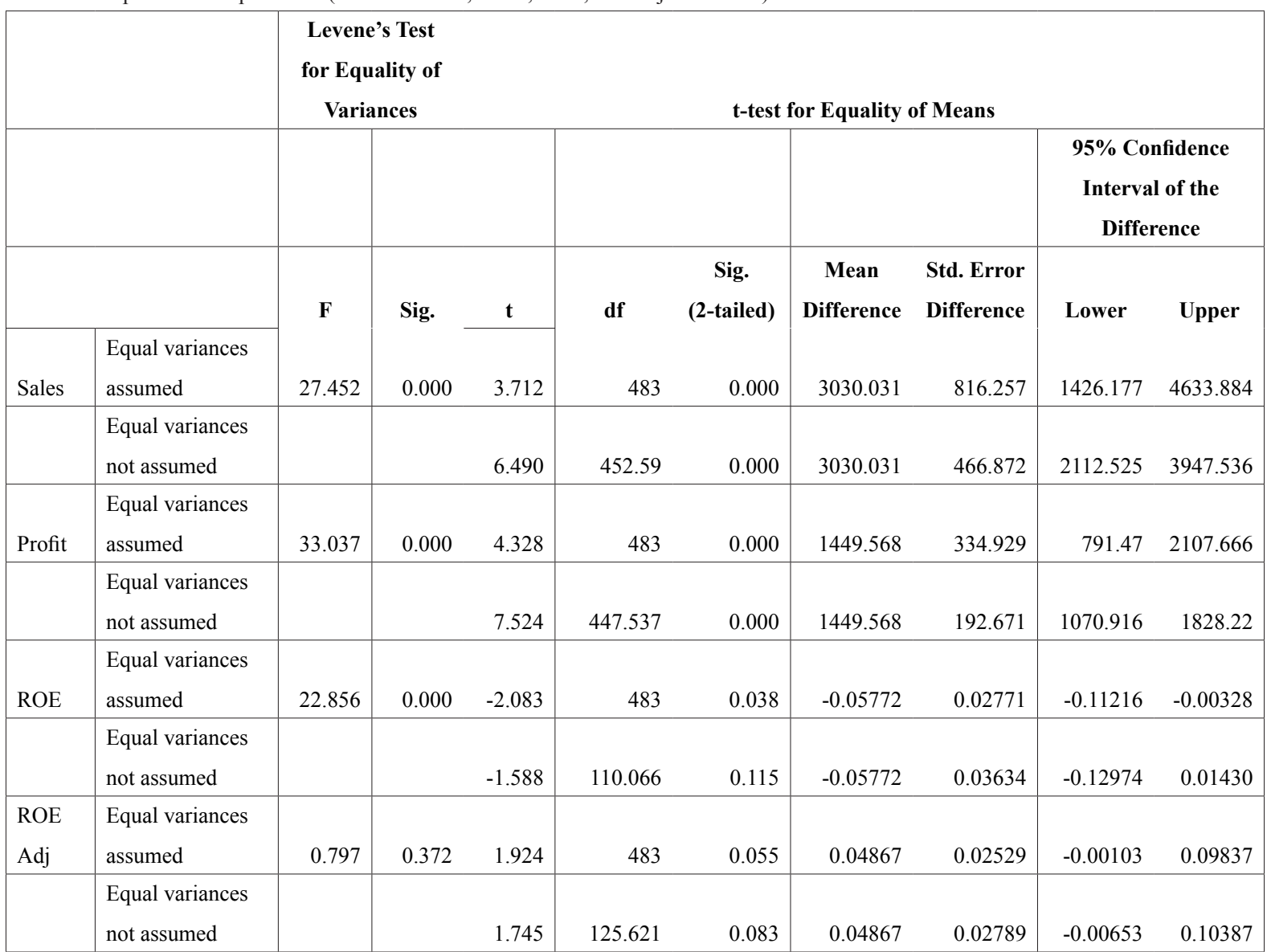

This finding is consistent with Hamdan, Othman, and Wan Hussin (2012) regarding the effectiveness of the YBK (Selangor), AIM, TEKUN, and LZS microfinance programs in increasing the participants' income. The study found that the average income of the asnafs under the EDP was at RM1,515, while the average income of the AIM participants was higher at RM2,038. The mean monthly income of RM2,520 found in this study is also consistent with the previous impact studies on AIM, as illustrated in Figure 1. In the figure, the average incomes of sahabats in 2008 and 2009 were RM2,639 and RM1,750, respectively. By contrast, aside from a study conducted by Hamdan, Othman, and Wan Hussin (2012), no known study exists on the income or profit of asnaf entrepreneurs under the PPUAZ program; thus, a comparison is not possible.
According to the Government Transformation Programme (GTP) 1.0 Roadmap, extreme poverty and poor in Peninsular Malaysia are those who earn less than RM460 and RM760, respectively. Table 3 further analyzes the income of the micro entrepreneurs on the basis of their net profit. From the table, $13.01 \%$ of sahabats and $22.58 \%$ of asnaf entrepreneurs are clearly still under the extreme poverty category, while $14.29 \%$ of sahabats and $21.51 \%$ of asnafs are still considered poor. Overall, approximately $73 \%$ of sahabats and $56 \%$ of asnafs manage to earn higher than the poverty line index (PLI) or over RM760 per month. These figures suggest that the earnings of the PPUAZ participants still seem to be at the unsatisfactory level when compared with those of the AIM participants because approximately $44 \%$ of them are still under the poor category. 
Table 3: Monthly Profit of the Micro Entrepreneurs (based on the poor and extreme poor definitions)

\begin{tabular}{|l|cc|cc|}
\hline & \multicolumn{3}{|c|}{ AIM } & \multicolumn{2}{c|}{ PPUAZ } \\
\hline Less than RM460 & 51 & $13.01 \%$ & 21 & $22.58 \%$ \\
\hline Between RM460 and RM760 & 56 & $14.29 \%$ & 20 & $21.51 \%$ \\
\hline More than RM760 & 285 & $72.70 \%$ & 52 & $55.91 \%$ \\
\hline
\end{tabular}

When compared with the study conducted by Hussin and Ahmad (2010), who found that only $6.9 \%$ of respondents who received capital aid from ZIs in Selangor and Kuala Lumpur managed to pass the Kifayah level of poverty, the present finding indicated that a major improvement occurred in the percentage of successful asnafs. Considering that the major improvement may also be influenced by the differences in the measurement of poverty level in both studies, such improvement may be attributed to the enhanced efficiency of PPUAZ in managing the EDP. Established in 2011, PPUAZ seems to have improved its mechanism in distributing capital assistance to the asnaf entrepreneurs in Selangor. All the program applicants are required to attend an entrepreneurship course as a prerequisite before receiving capital aid, which is focused on seven clustered projects (e.g., MyBurger and Mobile Entrepreneur). While the effectiveness of the program is still questionable, given that nearly half (or $44 \%$ ) of the asnafs covered in this study are still earning below the poverty line, the major increase from $7 \%$ successful asnafs in 2010 to $56 \%$ in this study should be commended.

Although the monthly sales and profit of sahabats are higher when compared with those of asnafs in this study, the average score of ROE of participants from PPUAZ is still higher at 0.2816 (standard deviation $=0.3349$ ) compared with that of AIM at 0.2238 (standard deviation $=0.2119$ ), as shown in Table 1. This finding suggests that, on average, the participants from PPUAZ are efficient in generating income based on the amount of capital invested. Nevertheless, this difference is not statistically significant at the 0.1 significant level, $\mathrm{t}(110)=-1.588, \mathrm{p}=$ $0.115>0.1$. It may be argued that the higher ROE score of PPUAZ respondents may be influenced by their non-repayment of the capital assistance provided by the PPUAZ. Based on the interview sessions with 12 AIM respondents, the percentage of AIM loan repayment to their total business expenses seems to be between $15 \%$ and $55 \%$. This finding is consistent with Hassan's (2013) study on the effectiveness of AIM in reducing poverty and improving the life quality of the sahabats. In the study, on average, $34.14 \%$ of the total expenses were used to repay their loan to AIM. Thus, assuming that the asnafs were required to repay the capital assistance provided by the PPUAZ, their expenses were increased by $30 \%$; the new adjusted profit was calculated as in Table 1. With the new adjusted figure, a new ROE was calculated for the PPUAZ respondents, and the average adjusted ROE was found to only be at 0.1752 , significantly lower than the ROE score of the sahabats. The p-value $=0.055$ suggests that the difference is statistically significant at the 0.1 level. Furthermore, the new profit calculation revealed that $5 \%$ of the asnafs were not making any profit, and another $10 \%$ would only make less than RM100 profit per month if they were to repay their capital assistance provided by the PPUAZ.

Overall, the financial performance of the AIM sahabat seems to be better than that of asnaf entrepreneurs based on the amount of sales, profit, and adjusted ROE in this study. This finding is consistent with the previous study by Hamdan, Othman, and Wan Hussin (2012), who suggested that the performance of AIM participants is better when compared with other poverty reduction programs, such as asnaf's EDP, TEKUN, and YBK. The present study further supported the arguments that although a few asnafs became successful entrepreneurs with the aid provided by the ZIs, many are still at the unsatisfactory level and fail to move out 
of the poverty level (Abd. Wahab 2012; Md. Ramli et al., 2010; Hussin \& Ahmad, 2010). However, when compared with Hussin and Ahmad's (2010) study, the present study found that a higher percentage of asnafs is earning more than the PLI.

\section{Non-Financial Performance}

Apart from financial performance, this study is also interested in understanding the nonfinancial performance of micro entrepreneurs under the two stipulated programs. As suggested by Reijonen (2008) and Fairbourne, Gibson, and Dryer (2007), the intentions of micro entrepreneurs were not oriented toward financial performance only but more toward other factors, such as satisfaction and quality of life. Categorized as "necessity entrepreneurs," these micro entrepreneurs "are pushed into entrepreneurship because all other options for work are either absent or unsatisfactory," suggesting that money is not their sole motivator but other factors as well, such as happiness, life satisfaction, and independence (Bosma \& Harding, 2006, p. 18). In line with Campbell (2007), this study uses non-financial measures, including business ownership, happiness, gratification, level of independence, and life improvement, to complement the financial measures in determining the performance of micro entrepreneurs.

Except for the life improvement factor, respondents were asked to rate their level of satisfaction on their happiness, independence, business satisfaction, and gratification using a five-item Likert scale. To measure the life improvement factor, respondents were asked to rate their satisfaction level on six items, namely, household income, asset ownership, housing condition, savings, children's education, and medical treatment, by comparing their current situation and their situation prior to joining the program, as summarized in Table 4. From the data gathered, a new variable (i.e., life improvement) was created based on the mean value of the six items.

Similar to the financial performance, an independent-sample t-test was conducted to compare the satisfaction level of the AIM and PPUAZ respondents with regard to their life improvement after joining the said program, as summarized in Tables 5 and 6. From the analysis, a significant difference was found in the scores for life improvement of participants in $\operatorname{AIM}(\mathrm{M}=3.645, \mathrm{SD}=0.7377)$ and PPUAZ $(\mathrm{M}=3.8405, \mathrm{SD}=0.5710) ; \mathrm{t}(173)=-2.795, \mathrm{p}=$ 0.006 . These results suggested that participants from PPUAZ are more satisfied with their life improvement after joining the asnaf's EDP when compared with the sahabats. To explore further, on average, the PPUAZ participants seemed to score higher in four components, namely, household income, savings, children's education, and family medical fees, when compared with the AIM sahabats, as tabulated in Table 4.

A similar test was done for other variables, namely, independence, happiness, business satisfaction, and gratification. The results were also tabulated in Tables 5 and 6 . As for independence, respondents were asked regarding their satisfaction level based on the premise "I enjoyed freedom and I have full control over my life" using a five-item Likert scale. From the test, a significant difference was observed in the scores for independence between AIM $(\mathrm{M}=3.60, \mathrm{SD}=0.896)$ and PPUAZ $(\mathrm{M}=$ $4.41, \mathrm{SD}=0.811) ; \mathrm{t}(483)=-7.966, \mathrm{p}=0.000$. Specifically, the results suggest that the asnafs from PPUAZ are more satisfied with their life freedom and have more control over their lives compared with the sahabats in AIM. 
Table 4: Components of Life Improvement

\begin{tabular}{|c|c|c|c|c|c|}
\hline & $\mathbf{N}$ & Minimum & Maximum & Mean & Std. Deviation \\
\hline \multicolumn{6}{|c|}{ Overall, my household income has improved since I joined AIM / asnaf's EDP. } \\
\hline AIM & 392 & 1 & 5 & 3.74 & 0.84 \\
\hline PPUAZ & 93 & 2 & 5 & 4.02 & 0.642 \\
\hline \multicolumn{6}{|c|}{ Overall, I have more assets now than prior to joining the AIM / asnaf's EDP. } \\
\hline AIM & 392 & 1 & 5 & 3.67 & 0.88 \\
\hline PPUAZ & 93 & 2 & 5 & 3.54 & 0.774 \\
\hline \multicolumn{6}{|c|}{ Currently, the condition of my house is better than prior to joining the AIM / asnaf's EDP. } \\
\hline AIM & 392 & 1 & 5 & 3.63 & 0.881 \\
\hline PPUAZ & 93 & 2 & 5 & 3.57 & 0.786 \\
\hline \multicolumn{6}{|c|}{ I have more savings now than prior to joining the AIM / asnaf's EDP. } \\
\hline AIM & 392 & 1 & 5 & 3.49 & 0.899 \\
\hline PPUAZ & 93 & 2 & 5 & 3.7 & 0.656 \\
\hline \multicolumn{6}{|c|}{ I am now able to provide better education for my children than prior to joining the AIM / asnaf's EDP. } \\
\hline AIM & 392 & 1 & 5 & 3.66 & 0.893 \\
\hline PPUAZ & 93 & 1 & 5 & 4.12 & 0.858 \\
\hline \multicolumn{6}{|c|}{ I am now able to pay for my family's medical fees if they are not well compared to before. } \\
\hline AIM & 392 & 2 & 5 & 3.68 & 0.889 \\
\hline PPUAZ & 93 & 2 & 5 & 4.1 & 0.822 \\
\hline
\end{tabular}

Table 5: Non-Financial Performance of Micro Entrepreneurs (based on the organizations)

\begin{tabular}{llcccc}
\hline & Organization & $\mathbf{N}$ & Mean & Std. Deviation & Std. Error Mean \\
\hline Life Improvement & AIM & 392 & 3.6450 & .73768 & .03726 \\
& PPUAZ & 93 & 3.8405 & .57099 & .05921 \\
\hline Independence & AIM & 392 & 3.60 & .896 & .045 \\
& PPUAZ & 93 & 4.41 & .811 & .084 \\
\hline Happiness & AIM & 392 & 3.45 & .914 & .046 \\
& PPUAZ & 93 & 4.08 & .935 & .047 \\
\hline Business Ownership & AIM & 392 & 3.62 & .903 & .094 \\
& PPUAZ & 93 & 4.01 & .907 & .046 \\
\hline Gratification & AIM & 392 & 3.68 & .801 \\
\hline
\end{tabular}


Table 6: Independent Sample t-Test (based on life improvement, independence, happiness, business satisfaction, and gratification)

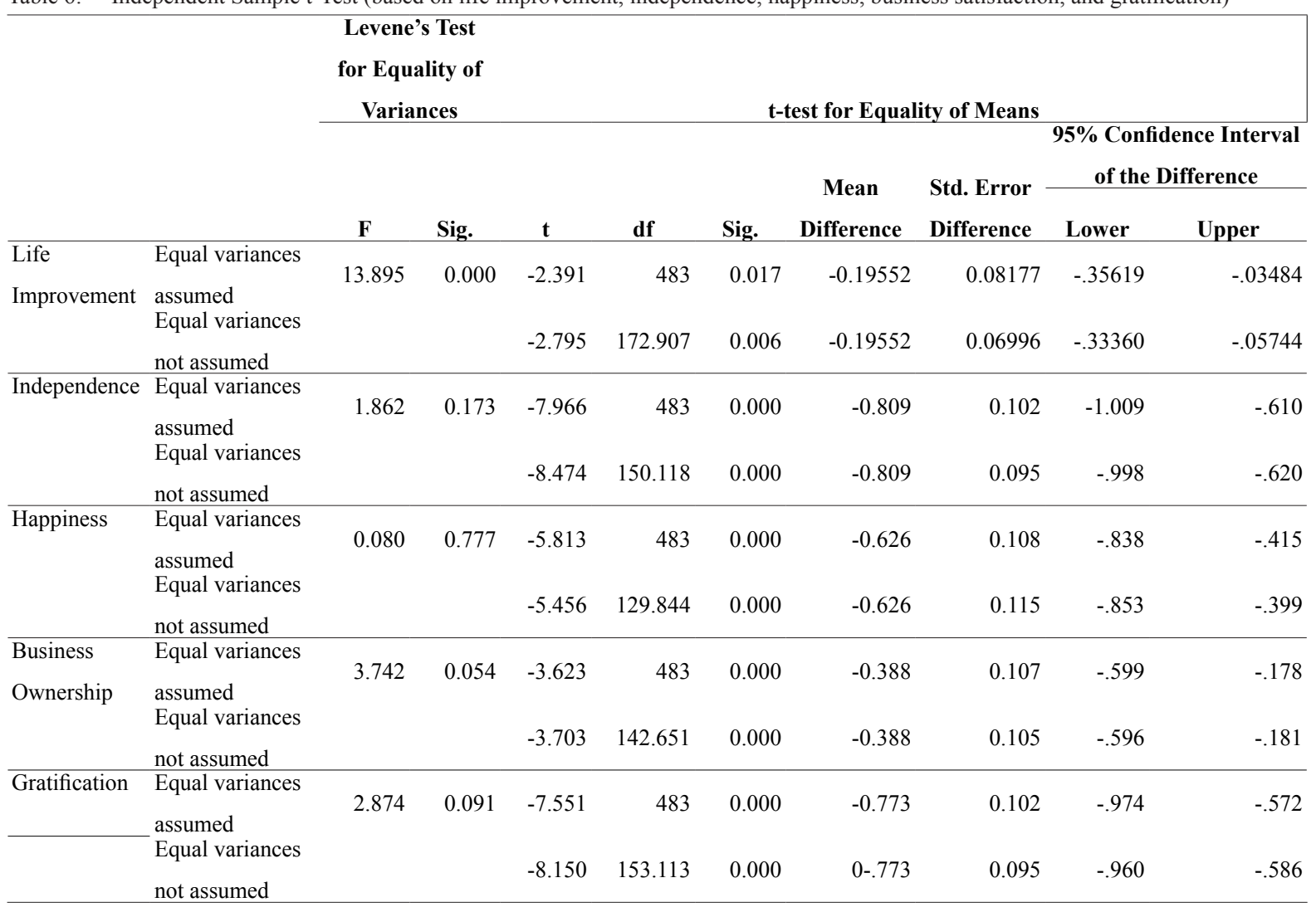

With regard to happiness, participants were asked regarding their satisfaction level on the statement, "I have achieved my personal satisfaction and happiness" using a Likert scale. From the analysis, PPUAZ respondents were found to have higher happiness scores $(\mathrm{M}=$ $4.08, \mathrm{SD}=1.013)$ than the AIM respondents $(\mathrm{M}=3.45, \mathrm{SD}=0.914), \mathrm{t}(483)=-5.813, \mathrm{p}=$ 0.000 . Moreover, despite the lower score in the financial performance of their businesses, PPUAZ respondents are more satisfied with their business ownership. In response to "I am satisfied with my business ownership," PPUAZ was found to score higher $(\mathrm{M}=4.01, \mathrm{SD}=$ $0.903)$ than $\operatorname{AIM}(\mathrm{M}=3.62, \mathrm{SD}=0.935), \mathrm{t}$ $(483)=-3.623, p=0.000$.

Further test was conducted to compare the gratification scores for AIM and PPUAZ respondents. A significant difference was observed in the gratification scores for AIM
$(\mathrm{M}=3.68, \mathrm{SD}=0.907)$ and PPUAZ $(\mathrm{M}=$ $4.45, \mathrm{SD}=0.801)$ participants. Specifically, these results suggested that PPUAZ respondents are more satisfied with their involvement in the micro enterprises when compared with the AIM respondents. To measure gratification, all respondents were asked to rate the statement "I have obtained personal satisfaction by working in this field" in a five-item Likert scale ranging from $1=$ very dissatisfied to $5=$ very satisfied.

Therefore, significant differences exist between the non-financial performances of AIM and PPUAZ respondents. From the independentsample t-test, the non-financial performance of the asnaf micro entrepreneurs seems to be better than that of the AIM sahabats based on the five measures, namely, business ownership, happiness, gratification, level of independence, and life improvement. 


\section{Conclusion}

The enterprise governance concept is vital for the long-term success of an organization, including micro entrepreneurs. Although AIM and PPUAZ have different mechanisms in providing financial assistance to micro entrepreneurs, both organizations have a similar main objective, which is to improve the socio-economic status of their participants, namely, sahabats and asnafs. Although previous impact studies on AIM indicatet that the program generally has a positive socio-economic impact to the sahabats, empirical studies on the economic development program under the ZIs (e.g., SZB) still suggest that the effectiveness of this program in alleviating poverty among asnafs is questionable. Theoretically, the cheaper the money, the less efficient its utility. Hence, whether the non-repayment nature of Zakat capital assistance contributed to this situation is interesting to understand.

Consistent with previous studies that highlighted the success of AIM in improving the financial and social conditions of the sahabats, this study found that, overall, the financial performance of sahabats is higher than that of the asnafs. Conversely, the non-financial performance of the asnaf entrepreneurs is better than that of the asnafs. These findings indicate that asnafs may financially perform lower than the sahabats, but they are generally more satisfied because they are not required to tackle several issues, such as loan repayments and free-riders in their groups.

The findings in this study indicate that both programs have their strengths and weaknesses. Although that AIM is effective in increasing the income of sahabats, this study still found that asnafs are generally more satisfied with their overall conditions. Therefore, this study proposes that ZIs (e.g., PPUAZ) should focus more on the hardcore poor, while MFIs (e.g., AIM) will focus more on the poor category. Under the PPUAZ program, the hardcore poor are subsequently not pressured to repay the financial assistance provided, and they may focus more on generating income to support themselves and their family members. After a certain period of time, with the collaboration between PPUAZ and AIM for example, these asnafs may then be transferred to the AIM program. Considering that AIM has other products and services to offer, the poor are expected to have other options to borrow extra money for their financial capital and for the expansion of their businesses. In the long run, the poor may generate significantly higher income compared to when they started their business with the PPUAZ. Such idea may motivate asnafs to work harder and avoid fully depending on the non-repayable finance under the Zakat funds.

However, given that this study was focused on the micro entrepreneurs in Selangor, the findings could not be generalized to other states in Malaysia or even to other countries. To overcome this situation, this study focused on two institutions considered the best in their own leagues. AIM is known as the biggest and most successful MFI in Malaysia, while PPUAZ is the pioneer ZI actively providing capital assistance to the asnafs. Therefore, although the findings from this study may not be generalized, the findings may still become the benchmark for other micro entrepreneurs from other institutions or areas. This finding is consistent with institutional theory, which it states that organizations tend to imitate best practices across industries to improve their performance. Moreover, owing to the financial and time constraints in conducting this research, this study exclusively focused on the financial and non-financial performances identified earlier. Other aspects could be explored in this area, thereby calling for future research.

\section{Acknowledgement}

The authors would like to express their gratitude to the Accounting Research Institute, Universiti Teknologi MARA and the Ministry of Education for funding and facilitating this research project. 


\section{References}

Ab Rahman, A., Alias, M. H. \& Syed Omar, S. M. N. (2012). Zakat Institutions in Malaysia: Problems and Issues. Global Journal A1Thaqafah, 2(1), 35-41.

Abdul Rahman, R. \& Ahmad, S. (2010). Pengukuran Keberkesanan Agihan Zakat: Perspektif Maqasid Al-Syariah. Paper presented at Seventh International Conference - The Tawhidi Epistemology: Zakat and Waqf Economy.

Abdul Rahman, R., Al Smady, A., \& Kazemian, S. (2015). Sustainability of Islamic Microfinance Institutions through Community Development. International Business Research, 8(6), 196-207.

Abdul Wahab, A. (2012, May). Economic Development Programme in Lembaga Zakat Selangor (MAIS) - Distribution of Capital Support. Lecture conducted at Intellectual Discourse in Islamic Microfinance.

AIM. (2016). AIM History. Retrieved February 1, 2016, from http://www.aim.gov.my/ cms/ englishversion/AboutUs/History.htm

Alam, M. M., Hassan, S., \& Said, J. (2015). Performance of Islamic microcredit in perspective of Maqasid Al-Shariah: A case study on Amanah Ikhtiar Malaysia. Humanomics, 31(4), 374-384.

Al-Qaradawi, Y. (1999). Fiqh al zakah (Volume 1): A comparative study of zakah, regulations and philosophy in the light of Quran and Sunnah. Saudi Arabia: King Abdul Aziz University.

Ball, A. S. (2016). Social Enterprise Governance. University of Pennsylvania Journal of Business Law, 18, 919-984.

Bosma, N. \& Harding, R. (2006). Global Entrepreneurship Monitor: 2006 Executive Report. Retrieved July 1, 2013 from http:// www.babson.edu/Academics/centers/blank-
center/global-research/gem/Documents/gem2006-global-report.pdf

Campbell, J. (2007). Why Would Corporations Behave in Socially Responsible Ways? An Institutional Theory of Corporate Social Responsibility. Academy of Management Review, 32(3), 946-967.

CIMA. (2007). Enterprise Governance, Topic Gateway series no. 32. United Kingdom: The Chartered Institute of Management Accounts.

Du Rietz, A., \& Henrekson, M. (2000). Testing the female underperformance hypothesis. Small Business Economics, 14(1), 1-10.

Fairbourne, J. S., Gibson, S. W. \& Dyer, W. G. (2007). MicroFranchising: Creating Wealth at the bottom of the Pyramid. Edward Elgar Publishing.

Gibbons, D.S., \& Kassim, S. (1990). Banking on the Rural Poor. Center for Policy Research, University Sains Malaysia.

Hadi, N. A., \& Kamaluddin, A. (2015). Social collateral, repayment rates, and the creation of capital among the clients of microfinance. Procedia Economics and Finance, 31, 823-828.

Hamdan, H., Othman, P. \& Wan Hussin, W. S. (2012). The Importance of Monitoring and Entrepreneurship Concept as Future Direction of Microfinance in Malaysia: Case Study in the State of Selangor. Journal of Global Entrepreneurship, 3(1), 1-25.

Honig, B. (1998). What Determines Success? Examining the Human, Financial, and Social Capital of Jamaican Microentrepreneurs. Journal of Business Venturing, 13, 371-394.

Hulme, D. \& Mosley, P. (Eds). (1996). Finance Against Poverty (Vol 2). Psychology Press, London. 
Hussin, A. \& Ahmad, S. (2010). Perbezaan Bantuan Modal Zakat Dan Kesannya Keatas Kejayaan Usahawan Asnaf Di Malaysia. Paper presented at Malaysia-Indonesia International Conference on Economics, Management and Accounting 2010: "Regional Development in an Era of Global Innovation Economy”.

Ibrahim, P. (2008). Pembangunan Ekonomi Melalui Agihan Zakat: Tinjauan Empirikal. Jurnal Syariah, 16(2), 223-244.

Kadri, N. F. (2011). The Role of Microfinance in Poverty Alleviation: AIM's Experience. Paper presented at The Development of Islamic Financial Service Industry.

Kazemian, S., Abdul Rahman, R., \& Ibrahim, Z. (2014). Measuring level of market orientation for an Islamic microfinance institution case study of Amanah Ikhtiar Malaysia (AIM). Qualitative Research in Financial Markets, 6(3), 258-277.

Kazemian, S., Abdul Rahman, R., Mohd Sanusi, Z., \& Adeyemi, A. A. (2016). Role of market orientation in sustainable performance: the case of a leading microfinance provider. Humanomics, 32(3), 352-375.

LZS. (2012). Annual Report. Retrieved April 5, 2014 from http://www.e-zakat.com.my/laporanlzs/

Loscocco, K. A., Robinson, J., Hall, R. H., \& Allen, J. K. (1991). Gender and small business success: an inquiry into women's relative disadvantage. Social forces, 70(1), 65-85.

Mamun, A. A. (2016). Access to Credit, Education and Entrepreneurial Competencies: A Study among Women Micro-entrepreneurs in Malaysia. Vision, 20(3), 159-168.

Md. Hassan, N., Mohd Nor, A. H., Mohd Rom, N. A. (2012). Embracing Microfinance: Proposed Collaboration Between Zakat Institution and Microfinance Institutions. Paper presented at the 3rd International Conference on Business and Economic Research Proceeding.

Md. Ramli et al., (2010). Understanding Asnaf Attitude: Malaysia's Experience in Quest for an Effective Zakat Distribution Programme. Paper presented at the International Zakat Conference: "Sustainable Development of Zakat in the Poverty Alleviation and Improvement of Welfare of the Ummah".

Mohd Balwi, M. A. W. F. \& Abd Halim, A. H. (2008). Mobilisasi Zakat Dalam Perwujudan Usahawan Asnaf: Satu Tinjauan. Jurnal Syariah, $16,567-584$

Omar, M. Z. (2010). The Role of Microcredit in Poverty Alleviation in Malaysia: The Case of Amanah Ikhtiar Malaysia. Paper presented at the Eight International Conference on New Directions in the Humanities.

PPUAZ. (2012). Projek Ekonomi Asnaf. Retrieved June 21, 2012 from http://ppuaz.ezakat.com.my/

Rahman, M. F. A., Rahman, A. A., Thaidi, H. A. A., Abdullah, L. H., Anwar, S. M., Bakar, M. F. A., \& Ahmad, U. S. (2013). The Inconsistency Of Assessing Agricultural Zakat. Global Journal Al-Thaqafah, 4(1), 17-31.

Reijonen, H. (2008). Understanding the Small Business Owner: What They Really Aim At and How This Relates to Firm Performance - A Case Study in North Karelia, Eastern Finland. Management Research News, 31(8), 616-629.

Revindo, M. D., \& Gan, C. (2017). Rural Microfinance Banking Viability and Outreach: A Case of Bank Rakyat Indonesia. In Microfinance in Asia (pp. 337-356). World Scientific.

Rhyne, E. (2001). Mainstreaming Microfinance: How Lending to the Poor Began, Grew and Came of Age in Bolivia. Bloomfield, CT: Kumarian Press. 
GJAT | JANUARY 2018 | SPECIAL ISSUE | 40

ISSN : 2232-0474 | E-ISSN : 2232-0482

www.gjat.my

Robb, A. M., \& Watson, J. (2012). Gender differences in firm performance: Evidence from new ventures in the United States. Journal of Business Venturing, 27(5), 544-558.

Robinson, M. S. (2001). The Microfinance Revolution: Suitable Finance for the Poor. World Bank Publications.

Sina, M. A., Sabur, M. A., \& Kamruzzaman, M. (2017). Impact of Grameen Bank Financing on the Rural Poor in Bangladesh. Australian Academy of Accounting and Finance Review, 2(1), 76-90.

Todaro, M. \& Smith, S. C. (2006). Development Economics. UK: Pearson Education Limited. 